\title{
Syaria Accounting Analysis of Murabahah Financing in Syaria Mandiri Bank Jambi Branch (Study Between Theory and Practice)
}

\author{
Mukhzarudfa $^{1}$ and Muhammad Qodri ${ }^{1}$ \\ \{1mukhzarudfa.jambi@gmail.com, ${ }^{2}$ muhammad.9odri18@yahoo.com\} \\ ${ }^{1}$ Jambi University, Indonesia
}

\begin{abstract}
This study analyzing murabahah financing products at the Jambi Syariah Mandiri Bank. When viewed from the needs of the community in meeting their needs, murabahah financing products are very important and more targeted than other financing products, because murabahah financing products are felt to be able to help the community's economy. Accounting is basically the recording medium as well as the calculation of economic activities including the variety of transactions. Thus, between record and count can be considered to be related to the meaning of account, measure, assess, evaluate, and even compute. Humans exist in the world, from its birth, essentially indirectly related to consumption and production activities. The history of science, including economics, was originally discovered and developed during the heyday of Islam with the ultimate goal being Falah (the happiness of the world-the hereafter materiallyspiritually) and its main base being the Tawhid sourced from the laws of the Qur'an and As Sunnah.
\end{abstract}

Keywords: Murabahah Product, Bank, and Community

\section{Introduction}

Islam is a universal religion that regulates all aspects of human life, in outline Islam regulates two main parts, namely worship and muamalah. Worship is a vertical relationship, which governs man in relating to Allah swt as his god. While muamalah is a horizontal relationship, namely activities that concern the relationship between humans and human beings covering aspects of economic, political, social and so forth. For muamalah activities concerning economic aspects such as buying and selling, savings and loans, accounts payable, joint ventures and so forth. Economic problems can not be separated from human life. It deals with a variety of needs, such as food, clothing and shelter, and other necessities. To fulfill the necessities of life, human beings should work by cultivating everything that has been provided in this universe, and from the results of these needs human needs can be met, both primary, secondary, and tertiary needs (Antonio, 2010). In fulfilling the necessities of life, human beings also have the same rights and obligations with each other, one does not harass the rights and duties of others with lust, greed, and greed. These forms of harassment include, among other things, the usury, the hoarding of property, not providing the proper wage of labor, manipulating the price, and monopoly. Sharia accounting based on the value of the Qur'an and Al-Hadith helps people to organize economic practices related to the recognition, measurement and recording of transactions and the disclosure of rights and duties fairly. Rights and obligations arise because humans are assigned by Allah SWT to manage the earth 
safely. So that accounting is actually a tool of accountability to the Creator and fellow creatures, used by humans to achieve their nature as khalifah (Muhmamad, 2009).

One syariah-based financing is murabahah financing, murabahah financing is one of the financing products in sharia banking that dominates and is much in demand by Indonesian society. This is evident from the May 2006 Indonesian Sharia Banking Statistics published by the Financial Services Authority. Murabahah transaction value was ranked first with 203.72 trillion rupiahs, followed by musyarakah with 64.52 trillion rupiah and mudharabah amounting to 14.86 trillion rupiah (Financial services authority, 2016). This statistic shows that Indonesian people are very interested in murabaha products offered by Bank Syariah in Indonesia. In murabahah financing required the accounting treatment, accounting treatment is an accounting system to see how the process of recording of financing products that use the system of sale and purchase of the parties involved into accounting systems used Islamic financial institutions. While the benefits of accounting treatment will have an impact on the sharia financial statements presented in accordance with SFAS No. 101 used to measure the performance of the presentation and disclosure of financial statements and useful for decision making. However, in reality, the accounting treatment of murabahah financing has not been balanced with good accounting treatment, the fact that there are still many entities or sharia banks that still violate the existing provisions in PSAK No. 102. Because providing financing to customers to obtain murabahah inventory and measure murabahah profit using annuity method is two accounting treatments regulated by PSAK 55. While in terms of recording in murabahah accounting treatment not yet in accordance with PSAK No. 102 and journal recording at the time of delinquency calculation based on PSAK No. 102. The development of Sharia Accounting in Indonesia dilator by the development of sharia financial institutions. In Indonesia there are many emerging Islamic financial institutions considering the number of people who are Muslims.

\section{Literature Review}

The pragmatic shariah accounting flow considers some conventional accounting concepts and theories to be used with some modifications. Modifications are made to pragmatic interests such as the use of accounting in Islamic companies that require the legitimacy of reporting based on Islamic values and sharia objectives. Such conventional accounting accommodation is patterned in accounting policies such as Accounting and Auditing Standards for Islamic Financial Institutions issued internationally by AAOIFI and PSAK No. 17. 59 or the most recent PSAK 101-106 in Indonesia.

\subsection{Theory of Sharia Accounting}

There has been a tremendous change in the field of accounting for the last few decades. Prior to the 1970s there was an assumption about accounting as a science and practice free of value (value free) has begun to shake its existence. In the era of information and globalization in the field of accounting there is a harmonization of accounting practices. Accounting practices in each country is considered difficult in interpreting the financial statements, or accounting practices that are unrarable uncomparable. This case invites the reaction of many people, views that are both pro and contra. Those who are counter-views criticize that actions to harmonize constitute harassment of local values.

Based on the above case, attempts to look for humanist, emancipatory, transcendental, and theological forms of accounting are a necessary undertaking. According to Iwan Triyuwono and Gaffikin it is said that Sharia Accounting is one of the attempts to modernize 
accounting into a humanist and full of values. The purpose of creating sharia accounting is the creation of business civilization with humanist, emancipatory, transcendental and theological insights. In this way, alternative reality is expected to generate full self-awareness of one's submission and submission to the power of God. With regard to the problem of theoretical changes, accounting will change to a new paradigm that has so far been unclear.

Murabahah is a sale and purchase agreement with the selling price of the acquisition cost plus the agreed profit and the seller must disclose the cost of the item to the buyer (SFAS 102 paragraph 5). This definition indicates that murabahah transactions do not have to be in the form of tough payments (credit), but can also be in cash after receiving the goods, suspended in installments after receiving the goods, or suspended by paying all at once in the future. Murabahah is the sale of goods at the cost of goods acquisition with additional benefits agreed between the seller and the purchaser of the goods. The apparent difference in the sale and purchase of murabahah is that the seller must disclose the price of the goods and then there is a negotiation of the profit which is agreed upon by both parties. In the murabaha agreement, the seller finances the purchase of goods required by the buyer. For example, murabahah transactions conducted in Bank Syariah, the Bank will buy the goods needed by customers from suppliers (suppliers) and then sell them to customers at a price plus a profit or mark-up.

The mechanisms performed in murabahah transactions conducted in the Sharia Banking sector are as follows:

- The Bank acts as a temporary seller of the customer as a buyer. The selling price is the purchase price of the bank from the manufacturer (factory / shop) plus the profit. Selling price and terms of payment must be agreed upon by both parties.

- The sale price is included in the trading agreement and if it has been agreed upon, it can not be changed during the term of the contract. In banking, murabaha is usually done by installment payment (bitsaman ajil).

- When there is goods, then immediately will be delivered to the customer, while the payment is done in a formidable.

Broadly speaking, buying and selling can be interpreted as the exchange of property on the basis of mutual. According to (Sabiq, 2008) buying and selling is to move the property with a replace (iwad) that can be justified (according to sharia). The exchange can be made between money with goods, goods with goods we used to know with barter and money with money such as exchange rate of rupiah currency with yen. Then there is the debate regarding the cost of acquisition, whether it is only the purchase price or at other costs. In general, the four madhhab scholars allow the direct charge to be paid to a third party. They do not allow the burden of direct costs associated with the work that the seller is supposed to do, as well as the cost of not adding value to the goods (Karim, 2001). The purchase price is the cost of the purchase price minus the purchase discount. If a discount is given after the contract, then the discount earned shall be the buyer's or seller's right in accordance with their agreement at the beginning of the contract. The amount of profit must be clear. The price of the agreed goods can not be changed. For example from the example above the agreed price Rp240 million and can be paid by installments of Rp10 million per month within 2 years. Then the amount of fixed installments of Rp10 million per month for 24 months even though the goods price has increased or the interest rate of the market increases.

The seller can be made in cash or credit (tough payments). In the murabaha agreement, different rates are permitted for different payment methods. For example, cash price, price tough with a period of 1 year or 2 years is different. But the seller and the buyer must choose which price is agreed in the contract and once agreed upon then there is only one price (the price in the contract) is used and this price can not be changed. Whether the buyer repays 
faster than the specified credit period or the buyer is delaying his payment, the price should not change.

If the contract of sale is tough and the buyer can pay it off in a timely manner or even he make a repayment faster than the period that has been set, then the seller gives a discount. However, the magnitude of this discount should not be promised at the beginning of the contract (to avoid any element of usury). If the buyer can not repay the debt according to the exact time set, the seller does not permit to impose a penalty on the buyer due to the overpayment of a debt equal to usury (see Chapter 4). Exceptions apply, if the buyer does not pay not because of financial difficulties but because of negligence. In such a case, the imposition of a fine is permitted. However, these penalties should not be recognized as sales revenue but should be used for a charitable / social fund (qard fund) to be distributed to people in need. The purpose of imposing a fine is as punishment / sanction for the negligent person to be more disciplined in fulfilling his debt obligation. If the repayment of the receivables is delayed because the buyer is experiencing financial difficulties, the seller should be relief. Waivers can include deleting the remaining bills, helping to sell murabaha objects on the other side to restructure the accounts. Debt restructuring is performed against debtors who experience a decrease in the ability of payment of receivables that are permanent. Debt restructuring can be done in the form (PSAK ED 108):

- Members cut the rest of the bill, so the number of installments to be small.

- Rescheduling, where the remaining bills remain (not allowed to be added) and extend the payment period in accordance with the agreement of both parties so that the amount of the installment becomes smaller.

- Convert a murabahah contract, by selling murabahah objects to the seller according to market price, then from the existing money used to pay off the remaining bill. The excess (if any) is used as an advance payment akad ijarah or as part of the capital of murabahah musyarakah or musharaka akad in the acquisition of a good. This can be done to debtors who experience a decrease in payment ability but the debtor is still prospective. Conversely, if there is a shortage remains a debt buyer whose payment method is mutually agreed.

\subsection{Type of Murabahah Covenant}

Murabahah with order (murabahah to the purchase order), In this type murabahah, the seller makes a purchase of goods after an order from the buyer. Murabaha with the order can be binding or not binding buyers to buy goods ordered. If it is binding, it means that the buyer must purchase the goods he ordered and can not cancel his order. If the murabaha asset purchased by the seller, in the murabahah of the order is binding, impaired before it is delivered to the buyer, the impairment becomes the seller's expense and will reduce the contract value.

\section{Result And Discussions}

Rukun and murabaha provisions, as follows:

a. Perpetrators

The perpetrator is lawful and baligh (intelligent and distinguishable), so buying and selling with a madman is illegitimate whereas a small child is considered legitimate, if his guardian seizes.

b. Buy and Sell Object, must meet the following requirements

- Goods traded are halal goods 
Then all goods that are forbidden by Allah, can not be used as objects of sale and purchase, because these goods can cause people to behave / violate the prohibition of Allah. This is in accordance with the following hadith.

"Allah forbid the sale of wickedness, carcasses, pigs, statues." (Bukhari Muslim)

"Allah, when forbidden anything, also forbids the price." (HR Ahmad and Abu Dawud)

- Goods traded must be profitable or of value, and not goods prohibited from sale, for example: the sale of goods that are expired

- The item is owned by the seller

The sale and purchase of goods not owned by the seller is invalid because how could he possibly hand over ownership of the goods to others for goods that are not his. Buying and selling by non-owner of this kind of goods, will only be valid if it gets permission from the owner of the goods.

- Such goods may be delivered irrespective of certain future events of unclear goods when the delivery is invalid, as it may generate uncertainty (gharar), which in turn may harm one of the transacting parties and may cause disputes.

- The goods must be known specifically and can be identified by the buyer so there is no gharar (uncertainty).

- The goods can know the quantity and quality clearly, so there is no gharar.

c. Ijab Qabul

Expressions and expressions of mutual acceptance among actors committed verbally, in writing, by correspondence or using modern means of communication

d. Treatment of accounting

Murabahah Accounting (PSAK 102 Revision 2013)

The scope of this SFAS is for shariah financial institutions and sharia cooperatives that melakuakn murabahah transactions both as a seller or pmbeli and other parties who conduct murabahah transactions with these entities.

\subsection{Accounting For Buyers}

a. Assets earned through murabahah transactions are recognized at cost of acquisition of cash.

Debt arising from a tough murabahah transaction is recognized as murabahah debt at the agreed purchase price (the amount required to be paid). The difference between the agreed purchase price and the cash cost as a deferred murabaha burden.

Journal (if there is no down payment)

Dr. Asset xxx

Dr. Death Murabahah Loan xxx

Cr. Murabahah Debt xxx

b. Deferred murabaha burden is amortized proportionally with the portion of murabaha debt repaid. Journal

Dr. Murabahah Debt xxx

Cr. Cash xxx

Dr. Burabah Burden xxx

Cr. Deferred Murabahah Loans xxx

\subsection{Accounting For Seller}

a. At the time of acquisition of murabahah asset is recognized as inventory at cost 


\section{Dr. Murabahah Asset xxx \\ Cr. Cash xxx}

b. For murabahah binding orders, the measurement of murabahah assets after acquisition is assessed at cost and in the case of impairment due to obsolete, worse or other conditions before being delivered to the customer, the impairment is recognized as an expense and reduces the asset value. If there is any impairment in value for the murabaha of the binding order

c. Fines resulting from negligence in performing obligations as the contract is recognized as a loss Journal:

$$
\text { Dr. The xxx fines }
$$

$$
\text { Cr. Cash / Debt xxx }
$$

d. Advances

Buyer pays advance, journal:

Dr. The xxx fines

Cr. Cash / debt Xxx

If you have made an advance, then when the goods are delivered, the journal:

Dr. Asset xxx

Dr. Death murabahah charges xxx

Cr. Down payment xxx

Cr. Murabahah debt xxx

If the buyer cancels the transaction and is charged, it is recognized as a loss. If the fee charged is less than the down payment, then the journal:

Dr. Cash xxx

Dr. Loss of fine $\mathrm{xxx}$

e. Presentation

Cr. Down payment xxx

Deferred murabahah burden is presented as a pcurang (contra account) murabahah money.

f. Disclosure

The buyer discloses matters relating to murabahah transactions, but is not limited to:

- The cash value of the asset obtained from the murabahah transaction

- Murabahah time period is tough

- Disclosures required in accordance with SFAS No. 101 on the presentation of sharia financial statements.

\section{References}

[1] Antonio, M. S. (2010) Bank Syariah Dari Teori ke Praktek. Jakarta: Gema Insani.

[2] Karim, A. A. (2001) Ekonomi Islam: Suatu Kajian Kontemporer. Jakarta: Gema Insani.

[3] Muhmamad, M. (2009) Paradigma Metodologi dan Aplikasi Ekonomi Syariah. Yogyakarta: Graha Ilmu. 